\title{
Comparison of Commercial and Local Varieties of Radish at Different Levels of Manures and Fertilizers
}

\author{
Tika Ram Chapagain'1, Sharmila Piya², Nabin Kumar Dangal², Jawahar Lal Mandal² \\ and Bhanu Prasad Chaudhary ${ }^{2}$ \\ ${ }^{1}$ National Commercial Agriculture Research Program, Pakhribas, Dhankuta \\ ${ }^{2}$ Agricultural Research Station, Pakhribas, Dhankuta \\ e-mail:chapagain_70@hotmail.com
}

\begin{abstract}
Five commercial (Any sesion, Tikimashi, Mino Early, Forty Days and Chetki) and a local (Bhedetar Local) varieties of radish were tested at the Agricultural Research Station (ARS), Pakhribas, Dhankuta, during the autumn season of 2008 and 2009 for their performance at different levels of manures and fertilizers. Two trials, varietal and fertilizer were conducted in randomized complete block design with four replications. The highest root yield (65.1 t ha $\left.{ }^{-1}\right)$ was obtained from Mino Early which was at par with Bhedetar Local $\left(62.85 \mathrm{t} \mathrm{ha}^{-1}\right)$ in varietal trial. In fertilizer trial, the highest mean root yield of Bhedetar Local was obtained from 100:80:40 $\mathrm{N}_{2}: \mathrm{P}_{2} \mathrm{O}_{5}: \mathrm{K}_{2} \mathrm{O} \mathrm{kg} \mathrm{ha}^{-1}+\mathrm{FYM} 20$ tha-1 which was at par with 75:50:50 N $2: \mathrm{P}_{2} \mathrm{O}_{5}: \mathrm{K}_{2} \mathrm{O} \mathrm{kg} \mathrm{ha}{ }^{-1}+\mathrm{FYM} 20 \mathrm{t} \mathrm{ha}^{-1}$, however, differed statistically with other treatments. The root yield obtained from the exiting farmers practice was statistically at par with 75:50:50 $\mathrm{N}_{2}: \mathrm{P}_{2} \mathrm{O}_{5}: \mathrm{K}_{2} \mathrm{O}$ kg ha-1. Root yield $\left(\mathrm{t} \mathrm{ha}^{-1}\right)$ was positively and significantly $(\geq 0.01)$ correlated with root length, plant height, root diameter and number of leaves per plant.
\end{abstract}

Key words: Bhedetar Local, fertilizers, radish,

\section{Introduction}

Radish (Raphanus sativus L.), one of the most popular root vegetable crops, can successfully be grown throughout the year in the hills of Nepal (Poon et al. 2004). Its popularity could be due to its wider climatic adaptation, easy cultivation methods and wider ranges of uses (Shrestha \& Shakya 2004). Area under radish was about 16,570 ha and total production was 2,19,230 tons with an average productivity of $13.23 \mathrm{t} \mathrm{ha}^{-1}$ in Nepal (VDD 2009). Likewise, the area coverage, production and productivity of radish in Dhankuta were 530 ha, 9,545 t and $18.01 \mathrm{t} \mathrm{ha}^{-1}$ respectively (DADO 2009). Farmers are growing very few recommended varieties of radish, however, many potential local radish cultivars are available in Nepal (Jha 2003). Mino Early, White Neck, Forty Days and Pyuthane Red are released varieties of radish in Nepal. Although neither registered nor released variety, Bhedetar Local is one of the highly productive, heat and moisture tolerant cultivar of radish from local farmers' collection (Gautam \& Khatiwada 1997). Besides these noble characteristics, the cultivar has not been found suitable for recommendation due to its large phenotypic variation in root yield and size (Gautam et al.1990). Therefore, purification work on this variety with bud pollination was started at Pakhribas Agricultural Centre (PAC) since 1996 (Gautam \& Khatiwada 1997) and its purification is still continued under cage through hand pollination. Now it is largely purified and ready for release (ARSP 2009). In order to prepare this variety for release, it was necessary to compare Bhedetar Local with other commercial varieties.

Appropriate variety selection and optimum nutrient supply is crucial for obtaining optimum yield from radish. Radish being a short duration and quick growing crop, the root growth should be rapid and uninterrupted. Hence, for the production of good 
quality roots and high yields, optimum fertilization with nitrogen and potassium is very important (Kale \& Massalkar 1993). Moreover, the reason for low production of radish in farmers' field is insufficient nutrient supply and lack of knowledge on suitable varieties (Gautam \& Khatiwada 1997).The same level of fertilizer may not be appropriate to all varieties. Hence, the fertilizer requirement of Bhedetar Local may vary with other commercial varieties. Therefore, this study was conducted to evaluate the performance of Bhedetar Local radish at different doses of fertilizers.

\section{Methodology}

\section{Varietal trial}

A field experiment was carried out during two consecutive autumn seasons of 2008 and 2009 at ARS, Pakhribas to compare cv. Bhedetar Local with other established commercial varieties of radish. Six varieties of radish namely: Any Season, Bhedetar Local, Tokinashi, Mino Early, Forty Days and Chetki Long were planted in randomized complete block design and replicated four times. Individual plot size was $2.7 \mathrm{~m}^{2}$ where $30 \mathrm{~cm}$ row to row and $15 \mathrm{~cm}$ plant to plant spacings were maintained by thinning after seedling establishment. Seed sowing was done during $2^{\text {nd }}$ week of September in both the years. Fertilizers @ 75:50:50 $\mathrm{N}_{2}: \mathrm{P}_{2} \mathrm{O}_{5}: \mathrm{K}_{2} \mathrm{O} \mathrm{kg} \mathrm{ha}{ }^{-1}$ and FYM @ $20 \mathrm{tha}^{-1}$ were applied in the soil.

\section{Manure and fertilizer trial}

A field experiment was carried out to find out the response of local radish cv. Bhedetar Local to different levels of organic and inorganic fertilizers at ARS, Pakhribas in two consecutive autumn seasons of 2008 and 2009. Seven different organic and inorganic sources of nutrient combinations were verified in randomized complete block design with four replications (Table 1 ). Plot size was $2.7 \mathrm{~m}^{2}$ where $30 \mathrm{~cm}$ row to row and $15 \mathrm{~cm}$ plant to plant spacings were maintained by thinning after seedling establishment. Seeds were sown during $2^{\text {nd }}$ week of September in both the years. Soil of the experiment site was analyzed before experiment where organic matter and nitrogen were found $1.61 \%$ and $0.1 \%$ respectively. Likewise phosphorus and potash were 23.80 and $52 \mathrm{~kg} \mathrm{ha}^{-1}$ respectively. $\mathrm{P}^{\mathrm{h}}$ of the experiment site was 6.16 .

Table 1. Treatment details of the fertilizer experiment

\begin{tabular}{|c|c|}
\hline S.N. & Treatments \\
\hline 1. & Control \\
\hline 2. & FYM $10 \mathrm{t} \mathrm{ha}^{-1}$ \\
\hline 3. & FYM 20 t ha $^{-1}$ \\
\hline 4. & $50: 50: 50 \mathrm{~N}_{2}: \mathrm{P}_{2} \mathrm{O}_{5}: \mathrm{K}_{2} \mathrm{O} \mathrm{kg} \mathrm{ha} a^{-1}+\mathrm{FYM} 20 \mathrm{tha}^{-1}$ \\
\hline 5. & Farmers' practice $\left(60: 50: 00 \mathrm{~N}_{2}: \mathrm{P}_{2} \mathrm{O}_{5}: \mathrm{K}_{2} \mathrm{O} \mathrm{kg} \mathrm{ha} \mathrm{a}^{-1}+\mathrm{FYM} 20 \mathrm{t} \mathrm{ha}^{-1}\right)$ \\
\hline 6. & $75: 50: 50 \mathrm{~N}_{2}: \mathrm{P}_{2} \mathrm{O}_{5}: \mathrm{K}_{2} \mathrm{O} \mathrm{kg} \mathrm{ha-1}+\mathrm{FYM} 20 \mathrm{t} \mathrm{ha}^{-1}$ \\
\hline 7. & 100:80:50 $\mathrm{N}_{2}: \mathrm{P}_{2} \mathrm{O}_{5}: \mathrm{K}_{2} \mathrm{O} \mathrm{kg} \mathrm{ha-1}+\mathrm{FYM} 20 \mathrm{t} \mathrm{ha}^{-1}$ \\
\hline
\end{tabular}

\section{Statistical Analysis}

Plant, root and yield characteristics were recorded during experimentation. Data were analyzed by analysis of variance. Microsoft Excel and MSTAT-C were used for the analysis. Mean separation was done by Duncan's multiple range test (DMRT).

\section{Results and Discussion Plant and root characteristics}

Varieties differed significantly ( $\left.\mathrm{pd}^{\prime \prime} 0.01\right)$ for plant height and biomass yield, however, they were statistically similar for root length and diameter (Table 2). Chetki Long was the tallest $(48.84 \mathrm{~cm})$ and Mino Early was the most dwarf $(39.35 \mathrm{~cm})$ variety. Chetki
Long and Forty Days were statistically at par while all other varieties were also statistically similar for height. The similar findings in Mino Early at PAC was reported by Khanal et al. (1990). The highest biomass yield was obtained from Mino Early and the lowest from Tokinashi. Root length and diameter did not vary among the radish varieties, however, the largest and longest roots were observed in Forty Days and Bhedetar Local, respectively. Similar observation in Bhedetar Local was also made by Gautam \& Khatiwada (1997). Plant height was significantly and positively correlated with root length and diameter, however, the tallest variety Chetki Long did not produce the longest root. 
Tika Ram Chapagain et al./Comparison of Commercial..........

Table 2. Fdiage and root characteristics of radish varieties

\begin{tabular}{l|l|l|l|l}
\hline Varieties & $\begin{array}{l}\text { Plant } \\
\text { height } \mathbf{( c m )}\end{array}$ & $\begin{array}{l}\text { Biomass } \\
\mathbf{( k g / p l o t )}\end{array}$ & $\begin{array}{c}\text { Root } \\
\text { Diameter(cm) }\end{array}$ & $\begin{array}{l}\text { Root length } \\
\text { (cm) }\end{array}$ \\
\hline Any Season & $41.7 \mathrm{bc} \uparrow$ & $20.62 \mathrm{ab}$ & 3.91 & 28.60 \\
Bhedetar Local & $43.4 \mathrm{bc}$ & $21.90 \mathrm{ab}$ & 4.42 & 35.40 \\
Chetki Long & $48.84 \mathrm{a}$ & $19.04 \mathrm{~b}$ & 4.14 & 25.04 \\
Forty Days & $45.90 \mathrm{ab}$ & $20.28 \mathrm{ab}$ & 4.73 & 24.26 \\
Mino Early & $39.35 \mathrm{c}$ & $23.75 \mathrm{a}$ & 4.34 & 33.70 \\
Tokinashi & $39.92 \mathrm{c}$ & $14.00 \mathrm{c}$ & 4.03 & 30.47 \\
F-test & $<.001$ & $<.001$ & $\mathrm{NS}$ & NS \\
LSD(p<0.05) & 4.57 & 3.87 & - & - \\
CV\% & 10.4 & 19.1 & 10.1 & 16.7 \\
\hline
\end{tabular}

${ }^{\dagger}$ Mean of 4 replications. In the columns means followed by the same letter are not significantly different $(\mathrm{p}<0.05)$ by DMRT. NS = Not significantly different.

\section{Root yield of radish varieties}

Radish varieties differed significantly (pd"0.01) for marketable root yield $\left(\mathrm{t} \mathrm{ha}^{-1}\right)$. The highest root yield (65.1 $\mathrm{t} \mathrm{ha}^{-1}$ ) was obtained from Mino Early which was at par with Bhedetar Local (62.85t ha ${ }^{-1}$ ) (Fig. 1). The similarity in root yield might be due to similar root length and diameter. Pandey and Pun (2004) reported maximum $59.53 \mathrm{t} \mathrm{ha}^{-1}$ root yield from Mino Early and 50.64 t ha $^{-1}$ from Forty Days at Bhakimli (1600-2300m) in Myagdi. The lowest root yield from Tokinashi was due to relatively short and small root size. Chapagain et al. (2000) reported $27.15 \mathrm{t} \mathrm{ha}^{-1}$ root yield from Tokinashi in farmers field at Fikkal, Ilam. Similarly 28.2 to $39.3 \mathrm{t} \mathrm{ha}^{-1}$ root yield of Tokinashi was recorded from organic kitchen garden at Pakhribas Agriculture Centre (PAC 1995). The root yield $\left(65.1 \mathrm{t} \mathrm{ha}^{-1}\right)$ was recorded from Bhedetar Local during rainy season at ARS, Pakhribas (ARS 2005). Number of plants per plot varied significantly due to poor germination of seeds of Tokinashi, however, plant population in other varieties was statistically at par. Number of plants per plot also affected the root yield of radish varieties. Covariate analysis of plant per plot showed significant effect of plant population on root yield.

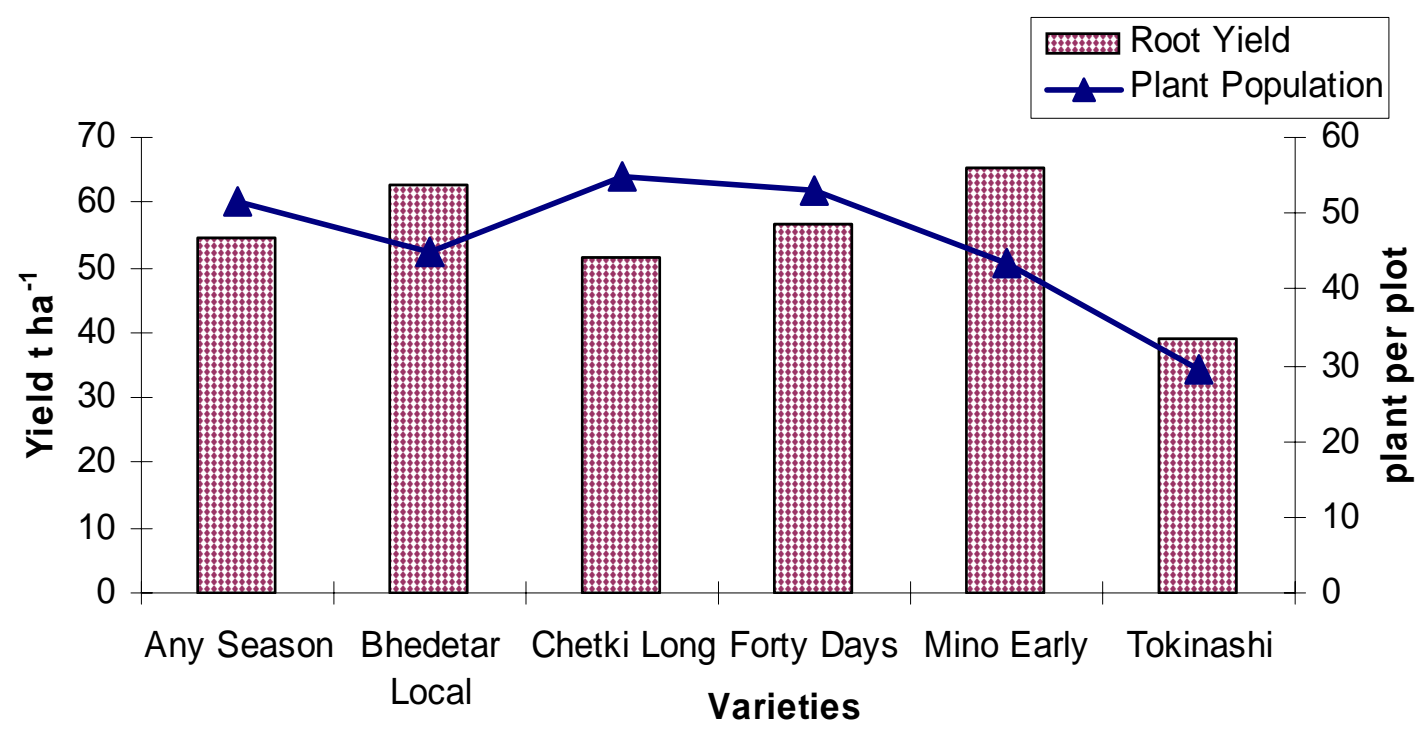

Fig. 1. Root yield ( $\mathrm{t} \mathrm{ha}^{-1}$ ) and plant population of radish varieties 


\section{Effect of fertilizers on plant and root characteristics of Bhedetar Local}

The plant height was increased according to increased doses of fertilizers. The highest plant height (47.72 $\mathrm{cm}$ ) was recorded in the plots treated with 100:80:50 $\mathrm{N}_{2}: \mathrm{P}_{2} \mathrm{O}_{5}: \mathrm{K}_{2} \mathrm{O} \mathrm{kg} / \mathrm{ha}+\mathrm{FYM} 20$ ton $\mathrm{tha}^{-1}$ and the lowest plant height $(26.52 \mathrm{~cm}$ ) form the control plot (Table 3 ). The stunted growth at lower fertility level clearly indicated that Bhedetar Local requires higher dose of fertilizer for normal growth. Number of leaves per plant and root diameter were also increased significantly with increased dose of fertilizers up to $75: 50: 50$ $\mathrm{N}_{2}: \mathrm{P}_{2} \mathrm{O}_{5}: \mathrm{K}_{2} \mathrm{O} \mathrm{kg} / \mathrm{ha}+\mathrm{FYM} 20$ ton $\mathrm{t} \mathrm{ha}^{-1}$ and declined marginally at 100:80:50 $\mathrm{N}_{2}: \mathrm{P}_{2} \mathrm{O}_{5}: \mathrm{K}_{2} \mathrm{O} \mathrm{kg} / \mathrm{ha}+\mathrm{FYM} 20$ ton $\mathrm{tha}^{-1}$. Fertilizer doses did not affect the root length of Bhedetar Local nor showed any clear growth pattern, however, significantly higher than those treatments without fertilizer use.

Table 3. Fdiage and root characteristics of Bhedetar Local

\begin{tabular}{|c|c|c|c|c|}
\hline Treatments & $\begin{array}{l}\text { Plant } \\
\text { height } \\
(\mathrm{cm})\end{array}$ & $\begin{array}{l}\text { No. of } \\
\text { Leaves per } \\
\text { plant }\end{array}$ & $\begin{array}{l}\text { Root diameter } \\
\text { (cm) }\end{array}$ & $\begin{array}{l}\text { Root length } \\
\text { (cm) }\end{array}$ \\
\hline 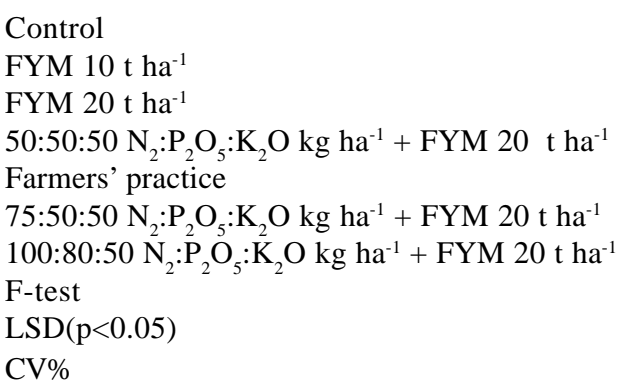 & $\begin{array}{l}26.52 \mathrm{~b}^{\dagger} \\
30.37 \mathrm{~b} \\
29.02 \mathrm{~b} \\
44.90 \mathrm{a} \\
41.92 \mathrm{a} \\
47.71 \mathrm{a} \\
47.72 \mathrm{a} \\
<.001 \\
6.73 \\
17.4\end{array}$ & $\begin{array}{l}16.23 \mathrm{c} \\
16.67 \mathrm{bc} \\
18.30 \mathrm{abc} \\
18.65 \mathrm{abc} \\
19.67 \mathrm{ab} \\
20.48 \mathrm{a} \\
20.40 \mathrm{a} \\
0.04 \\
3.08 \\
16.4\end{array}$ & $\begin{array}{l}3.81 \mathrm{~b} \\
3.83 \mathrm{~b} \\
4.02 \mathrm{~b} \\
4.61 \mathrm{a} \\
4.71 \mathrm{a} \\
4.7 \mathrm{a} \\
4.6^{\mathrm{a}} \\
<.001 \\
0.54 \\
12.5\end{array}$ & $\begin{array}{l}30.63 \\
34.03 \\
34.40 \\
37.65 \\
33.75 \\
38.20 \\
36.88 \\
\text { NS } \\
- \\
17.2\end{array}$ \\
\hline
\end{tabular}

${ }^{\dagger}$ Mean of 4 replications. In the columns means followed by the same letter are not significantly different (pd"0.05) by DMRT. NS = Not significantly different.

\section{Root yield of Bhedetar Local at different doses of fertilizers}

Fertilizer doses significantly affected the root yield of Bhedetar Local radish. The highest mean root yield was obtained from 100:80:50 $\mathrm{N}_{2}: \mathrm{P}_{2} \mathrm{O}_{5}: \mathrm{K}_{2} \mathrm{O} \mathrm{kg}$ ha $^{-1}+$ FYM 20 t ha $^{-1}$ which was at par with 75:50:50 $\mathrm{N}_{2}: \mathrm{P}_{2} \mathrm{O}_{5}: \mathrm{K}_{2} \mathrm{O} \mathrm{kg} \mathrm{ha-1}+$ FYM $20 \mathrm{t} \mathrm{ha}^{-1}$, however, differed statistically with the other treatments (Fig. 2). The lowest root yield was obtained from control, however, it was at par with $10 \mathrm{t} \mathrm{ha}^{-1}$ FYM. This condition might be due to the residual nutrients available in the soil. However, organic matter, phosphorus and potash were low and nitrogen was in medium condition in the experiment site before experiment. The root yield obtained from the exiting farmers practice (60:50:00 $\mathrm{N}_{2}: \mathrm{P}_{2} \mathrm{O}_{5}: \mathrm{K}_{2} \mathrm{O} \mathrm{kg} \mathrm{ha}{ }^{-1}+\mathrm{FYM}$ $20 \mathrm{t} \mathrm{ha}^{-1}$ ) was statistically at par with 75:50:50 $\mathrm{N}_{2}: \mathrm{P}_{2} \mathrm{O}_{5}: \mathrm{K}_{2} \mathrm{O} \mathrm{kg} \mathrm{ha}{ }^{-1}+$ FYM 20 t ha $^{-1}$. The similarity in root yield between 10 and $20 \mathrm{tha}^{-1}$ FYM could be due to under utilization of FYM by radish in short period of time. Adhikari and Pathak (1999) recorded the highest root yield (63.64 $\mathrm{t} \mathrm{ha}^{-1}$ ) from Mino Early with application of 60:30:60 $\mathrm{N}_{2}: \mathrm{P}_{2} \mathrm{O}_{5}: \mathrm{K}_{2} \mathrm{O} \mathrm{kg} \mathrm{ha}{ }^{-1}+\mathrm{FYM}$ $20 \mathrm{t} \mathrm{ha}^{-1}$ and $20 \mathrm{~kg} /$ ha borax in Pokhara condition. The highest plant population per plot was recorded in the plots treated with 50:50:50 $\mathrm{N}_{2}: \mathrm{P}_{2} \mathrm{O}_{5}: \mathrm{K}_{2} \mathrm{O} \mathrm{kg} \mathrm{ha}{ }^{-1}+\mathrm{FYM}$ $20 \mathrm{t} \mathrm{ha}^{-1}$. However, covariate analysis of plant population per plot showed non significant effect of plant population on root yield.

\section{Correlation study}

Root yield ( $\mathrm{t} \mathrm{ha}^{-1}$ ) was positively and significantly $(<0.01)$ correlated with root length, plant height, root diameter and number of leaves/plant (Table 4). The correlation study revealed that the value of these factors/characters increased, the root yield can be increased. Similar findings have been reported by Verman and Singh (1989). Plant height was also significantly and positively correlated with root length and diameter. 


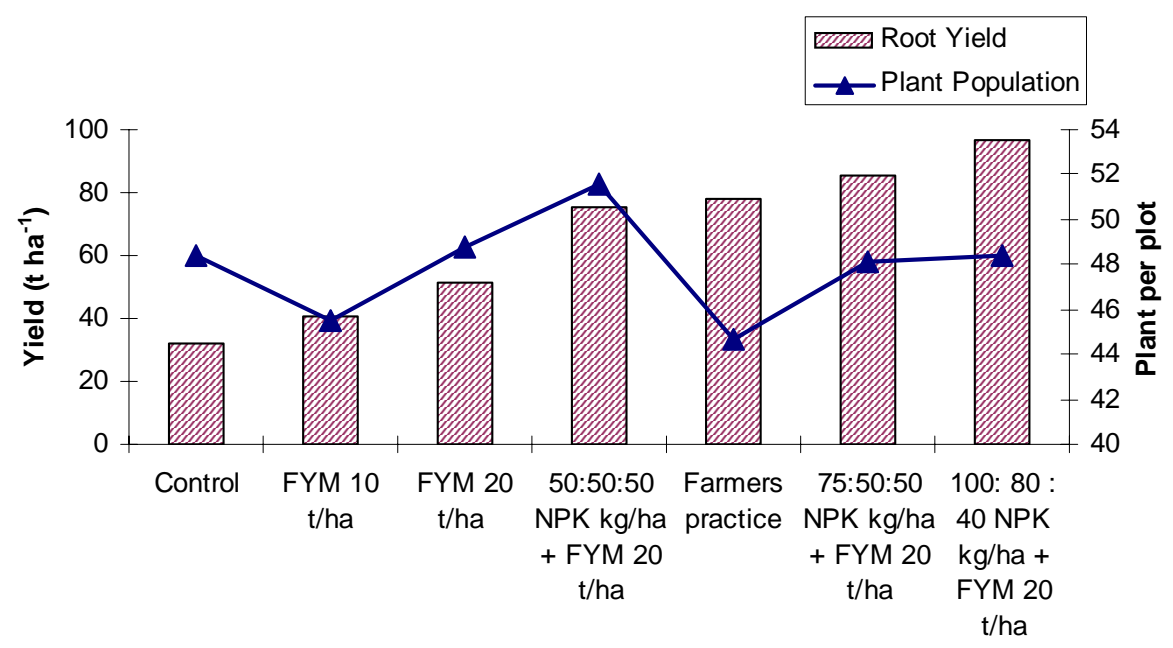

Fertilizer Dose

Fig. 2. Root yield and plant population at different doses of fertilizers

Table 4. Correlation between major plant characters and root yield $\left(\mathrm{t} \mathrm{ha}^{-1}\right)$

\begin{tabular}{l|c|c}
\hline Plant characters & Correlation & $\begin{array}{c}\text { Coefficient } \\
\text { Probability }\end{array}$ \\
\hline Plant height & 0.816 & $\mathrm{~d}^{\prime \prime} 0.01$ \\
Root length & 0.640 & $<.001$ \\
Root diameter & 0.663 & $<.001$ \\
No. of leaves & 0.621 & $<.001$ \\
\hline
\end{tabular}

Bhedetar Local is one of the suitable radish varieties for commercial cultivation and it is also appropriate for release. To increase the overall productivity of radish, farmers have to increase the level of nutrient they currently applying.

\section{Acknowledgements}

We are thankful to Nepal Agricultural Research Council for providing the research fund for this study.

\section{References}

Adhikari, B.H. and H.P. Pathak.1999. Effect of different boron levels on radish (Raphanus sativus L. var. Mino Early) production in pokhara valley of Nepal. In: Proceedings of Third National Conference on Science and Technology (8-11 March 1999). Royal Nepal Academy of Science and Technology, Kathmandu, Nepal. Vol.2. pp. 810-815.
ARSP. 2009. Technology development on Bhedetar Loca Iradish. Annual Report. pp. 44.

ARSP.2005. Performance of Bhedetar Local in rainy season. Annual Report. pp. 18

Chapagain, T.R., T.P. Barakoti, K.P. Shrestha and T.P. Paudel. 2000. Highlights of technical research activities at the outreach sites of Agricultural Research Station, Pakhribas. In: Proceedings of the Fifth National Outreach Research Workshop (30-31 May 2000) (Eds. M. Joshi, D. Gauchan and N. Thakur). Outreach Research Division, Nepal Agricultural Research Council, Khumaltar. pp. 194-203.

DADO. 2009. Annual Report. Distirct Agriculture Development Office, Dhankuta, Nepal.

Gautam, I. P. and P.P. Khatiwada. 1997. Results on purification of Bhedetar Local radish. Working paper no. 205. Pakhribas Agricultural Centre, Dhankuta, Nepal, pp. 1-6.

Gautam, S.R., G. Neupane and M.P. Thapa. 1990. Results of experiments on vegetable crops at PAC. Technical paper no. 106. Pakhribas Agricultural Centre, Dhankuta, Nepal, pp 1-7.

Jha, A.K. 2003. Observational study for radish germplasms for main and off season production in the eastern hills. In: Proceedings of the third national horticultural research workshop (7-8 June 2000) (Eds. K.P. Paudyal, P.P.Khatiwada, B.B.Khatri,). Nepal Agricultural Research Council, Khumaltar. pp. 61-67.

Kale, P. N. and S. D. Masalkar. 1993. Agro-techniques for root crops. In: Advances of Horticulture Vol. 5. 
Nepal Journal of Science and Technology 11 (2010) 51-56

Vegetable crops (Eds. K.L. Chadha \& G. Kalloo). Malhotra Publishing House, India.

Khanal, R., P.R.Neupane and A.J.Ghimire.1990.Cultivar characters study of vegetable crops at PAC. Technical paper no. 141. Pakhribas Agricultural Centre, Dhankuta, Nepal, pp. 7-9.

PAC.1995. Annual Report-1994-95. Pakhribas Agricultural Center, Pakhribas, Dhankuta. 43pp.

Pandey, Y.R. and A.B. Pun. 2004. Participatory varietal evaluation of vegetable crops in the western hills of Nepal. In: Proceedings of the Fourth National Workshop on Horticulture (2-4 March 2004) (Eds.B.B.Khatri, B.P.Sharma, P.P.Khatiwada, K.P. Paudyal, B.R. Khadge and H.N.Regmi). Nepal Agricultural Research Council, Khumaltar. pp. 377-379.

Poon, T.B., H. N. Regmi and O.B. Woli. 2004. Influence of plant spacing on seed yield of radish Mino Early. In:
Proceedings of the fourth national workshop on horticulture (2-4 March 2004) (Eds.B.B.Khatri, B.P.Sharma, P.P.Khatiwada, K.P. Paudyal, B.R. Khadge and H.N.Regmi). Nepal Agricultural Research Council, Khumaltar. pp. 373-376.

Shrestha, M.M. and S.M.Shakya. 2004. Response of radish crop var. fourty days to transplanting age and detopping in respect to seed yield. In: Proceedings of the fourth national workshop on horticulture (2-4 March 2004)(Eds.B.B.Khatri, B.P.Sharma, P.P.Khatiwada, K.P. Paudyal, B.R. Khadge and H.N.Regmi). Nepal Agricultural Research Council, Khumaltar. pp. 377-379.

Verma, O.P. and P.V. Singh.1989. Association of seedling root length with edible root length and yield in radish. Seeds and Farms 15(2):19-20.

VDD. 2009. Annual progress report (2065/2066). Vegetable Development Directorate, Agriculture Department, Ministry of Agriculture, Nepal. pp. 89. 